\title{
The Effect of Different Weed Management Strategies on the GROWTH AND YIELd OF DIRECT-SEEDED DRY RICE (Oryza sativa) $^{1}$
}

\author{
O Efeito de Diferentes Estratégias de Manejo de Plantas Daninhas sobre o Crescimento e a \\ Produtividade de Arroz (Oryza sativa) Semeado em Plantio Direto
MUHAMMAD, S. ${ }^{2}$, MUHAMMAD I. $^{3}$, SAJID, A. ${ }^{4}$, MUHAMMAD, L. ${ }^{2}$, MAQSHOOF , A. ${ }^{2}$, and NADEEM, A. ${ }^{5}$

\begin{abstract}
Weed management is a primary concern in direct seeded rice (DSR) cropping because weed growth becomes a major constraint on crop yield. A two year field study was set up to evaluate the effect of various weed control measures on crop growth, grain yield and grain quality of DSR. The experiment involved five different weed control measures: hand weeding, hoeing, inter-row tine cultivation, inter-row spike hoeing and herbicide treatment (Nominee $100 \mathrm{SC}$ ). The extent of weed control (compared to a non-weeded control) ranged from 50-95\%. The highest crop yield was obtained using hand weeding. Hand weeding, tine cultivation and herbicide treatment raised the number of fertile rice tillers formed per unit area and the thousand grain weight. Tine cultivation provided an effective and economical level of weed control in the DSR crop.
\end{abstract}

Keywords: herbicides, direct seeded rice, grain yield, tine cultivator.

RESUMO - O manejo de plantas daninhas é uma preocupação primordial do arroz semeado em plantio direto (ASPD), pois o crescimento delas se torna uma grande restrição ao rendimento das culturas. Um estudo de campo de dois anos foi estabelecido para avaliar o efeito de várias medidas de controle de plantas daninhas sobre o crescimento das culturas, produção de grãos e qualidade de grãos de ASPD. O experimento envolveu cinco medidas diferentes de controle de plantas daninhas: capina manual, capina, cultivo entre fileiras com forcado, capina com ferramenta agricola em entrelinhas e tratamento com herbicida (Nominee $100 \mathrm{SC}$ ). A extensão do controle das plantas daninhas (em comparação com o controle não capinado) variou entre 50\% e 95\%. A maior produtividade da cultura foi obtida utilizando-se capina manual. Capina manual, cultivo com forcado e tratamento com herbicida aumentaram o número de perfilhos férteis de arroz formados por unidade de área e peso de mil grãos. O cultivo com forcado proporcionou nivel eficaz e econômico de controle de plantas daninhas na cultura do ASPD.

Palavras-chave: herbicidas, arroz em plantio direto, rendimento de grãos, cultivo com forcado.

\section{INTRODUCTION}

Half of the world's population has fulfilled its food calories intake through rice (Farooq et al., 2011). The conventional method of paddy rice production is labor intensive and requires a lot of water (Matloob et al., 2015a). On the other hand, there is an increase in irrigation water scarcity throughout the world or in rice cultivation areas these days and manual labor

Recebido para publicação em 24.7.2015 e aprovado em 23.9.2015.

2 University College of Agriculture and environmental Science, The Islamia University of Bahawalpur, Pakistan, ${ }^{3}$ College of Agriculture, Bahauddin Zakariya University, Bahadur Sub Campus, Layyah, Pakistan, < muhammad.ijaz@bzu.edu.pk>; ${ }^{4}$ University of the Punjab, Lahore, Pakistan; ${ }^{5}$ University of Agriculture, Faisalabad, Pakistan, 
costs are increasing more compared to the increase in crop prices (Saqib et al., 2012). Maintaining food security in Asia demands the expansion of new rice production systems, which reduce the irrigation water and avoid the need for manual transplanting; one such system is direct rice seeding into dry soil (Matloob et al., 2015b). Weed growth is generally suppressed in puddled and flooded rice cultivation due to the presence of anoxic soil environment conditions (Chauhan et al., 2011); however, in dry land rice production systems, there is less weed suppression and is the major problem in this rice cultivation system (Ladha et al., 2007).

In some countries, including Pakistan, farmers are shifting from rice seedlings transplantation under flooded conditions to direct-seeded rice (DSR) due to the increase in irrigation water scarcity or increase in manual labor costs which lead to increase in cost of rice crop production. Chemical weed control is one of the methods used to control weeds in DSR, but due to concerns about the development of resistance and an insufficiency of new and effective herbicides, there is a need to integrate other weed management strategies along with chemical control (Chahal et al., 2014, 2015). Because of the variability in the growth habit of weeds, no single method of weed control can provide effective and season-long control in DSR (Aulakh et al., 2013). Various weed management approaches need to be integrated to achieve an effective, sustainable, and longterm weed control in DSR (Beckie, 2011). These approaches may include tillage systems; mulching by crop residues; use of weedcompetitive cultivars; manual or mechanical weeding; and appropriate herbicide timing, rotation, and combination (Chauhan et al., 2012).

Manual weeding is an effective means of controlling weeds, but a declining labor force in the rural areas along with the rising cost of labor have encouraged the usage of herbicides (Fischer et al., 2004). Selective herbicides (Bispyribac-sodium) are easy to use, effective and not expensive (Khaliq et al., 2014). However, continuous use of herbicides risks the development of genetic resistance, and there are potential downsides to the widespread use associated with their impact on non-farmland vegetation and human health (Johnson \& Mortimer, 2005; Khaliq et al., 2012). The long term sustainability of direct-seeded rice (DSR) systems requires weed management practices which promote resource conservation, being also environmental friendly (Singh et al., 2011). The present study set out to assess the influence of various weed control measures on the productivity and end use quality of DSR. The objective of this study was to identify the best suitable method of weed control in DSR.

\section{MATERIAL AND METHODS}

A field experiment was conducted over the years of 2008 and 2009 at the University of Agriculture, Faisalabad, $\left(31^{\circ}-25^{\prime} \mathrm{N}, 73^{\circ}-09^{\circ} \mathrm{E}\right)$ with a sandy loam soil having $\mathrm{pH} 8.5$, cation exchange capacity of $2.01 \mathrm{dS} \mathrm{m}^{-1}$ and organic matter contents at $0.78 \%$. Meteorological data of the experimental site during the rice seasons of 2008 and 2009 are given in Table 1. Pre-crop was wheat in 2008 and 2009. A tractor-mounted automatic seed-drill was used for seeding, with an inter-row distance of $22.5 \mathrm{~cm}$, seeding rate was $75 \mathrm{~kg} \mathrm{ha}^{-1}$ and rice cultivar Super Basmati. In both years seeding was done at end of June. Phosphorus $\left(85 \mathrm{P}_{2} \mathrm{O}_{5} \mathrm{~kg} \mathrm{ha}^{-1}\right)$ and potassium $\left(67 \mathrm{~K}_{2} \mathrm{O} \mathrm{kg} \mathrm{ha-1}\right)$ were incorporated into the soil prior to planting. Nitrogen $\left(150 \mathrm{~kg} \mathrm{ha}^{-1}\right)$ was applied in three equal splits of $50 \mathrm{~kg} \mathrm{ha}^{-1}$ at 10, 28 and 50 days after sowing (DAS) in both years. Irrigation was applied at all the critical stages of the crop. Water was not allowed to stand for more than one day.

The weed control treatments compared were (1) manual weeding (direct hand), (2) hoeing, (3) weeding between rows using a tine cultivator, (4) weeding between rows using a spike hoe, (5) bispyribac sodium @ $250 \mathrm{~mL} \mathrm{ha}^{-1}$ (Nominee $100 \mathrm{SC}$ ) and (6) control plot which was not weeded. Treatments 1 to 4 were carried out four times, at 15, 25, 35 and 45 DAS. The herbicide was manually applied by using a knapsack sprayer producing a median droplet range of 200 to 300 microns VMD (Volume Median Diameter) using 250 liters of water per hectare at 15 DAS. The crop was laid down after the implementation of tine cultivator and spike hoe, just like 
Table 1 - Local weather data collected during the 2008 and 2009 growing seasons

\begin{tabular}{|c|c|c|c|c|c|c|c|c|c|c|}
\hline \multirow{3}{*}{ Month } & \multirow{2}{*}{\multicolumn{2}{|c|}{ Rainfall (mm) }} & \multirow{2}{*}{\multicolumn{2}{|c|}{ Relative Humidity (\%) }} & \multicolumn{6}{|c|}{ Temperature $\left({ }^{\circ} \mathrm{C}\right)$} \\
\hline & & & & & \multicolumn{2}{|c|}{ Max. } & \multicolumn{2}{|c|}{ Min. } & \multicolumn{2}{|c|}{ Daily Average } \\
\hline & 2008 & 2009 & 2008 & 2009 & 2008 & 2009 & 2008 & 2009 & 2008 & 2009 \\
\hline June & 41.7 & 9.6 & 48.00 & 33.6 & 38.4 & 40.7 & 27.4 & 27.0 & 32.9 & 33.8 \\
\hline July & 81.6 & 43.5 & 52.97 & 59.0 & 37.5 & 38.0 & 28.3 & 27.9 & 32.9 & 32.9 \\
\hline Aug & 204.5 & 116 & 65.00 & 65.8 & 35.1 & 36.6 & 26.8 & 27.6 & 30.9 & 32.1 \\
\hline Sept & 28.8 & 20.6 & 59.33 & 61.0 & 34.4 & 36.3 & 23.7 & 24.4 & 29.0 & 30.3 \\
\hline Oct & 0 & 17.5 & 57.65 & 57.9 & 33.1 & 32.7 & 20.2 & 17.1 & 26.6 & 24.9 \\
\hline Nov & 0 & 0.7 & 58.87 & 64.7 & 27.3 & 25.7 & 12.2 & 10.8 & 19.7 & 18.2 \\
\hline
\end{tabular}

Source: Agricultural Meteorology Cell, Department of Crop Physiology, University of Agriculture, Faisalabad.

beushening. In both seasons, the experiment was arranged in a complete randomized block design $(\mathrm{RCBD})$ with three replications.

Weeds were manually collected from a $100 \times 100 \mathrm{~cm}$ quadrat within each plot at 45 DAS, uprooted, washed with water, separated into sedges and broad-leaved weeds, oven-dried at $70{ }^{\circ} \mathrm{C}$ for $72 \mathrm{~h}$, and then weighed. At maturity, the crop was harvested and the number of fertile tillers, the number of grains per panicle, the thousand grain weight and grain yield (at 14\% moisture content) were measured. The leaf area index (LAI) was calculated from the ratio of total leaf area, which was calculated by leaf area meter (JVC-TK-5310) to land area according to the expression. LAI was measured fortnightly by using the leaf area. The crop's growth rate (CGR) was estimated by using the following formula (Hunt, 1978).

$$
C G R=\left(w_{2}-w_{1}\right) /\left(t_{2}-t_{1}\right)
$$

\section{Statistical Analysis}

Collected data was statistically analyzed by using software Statistic 8.1. Means differing from one another by one or more $\mathrm{LSD}_{0.05}$ were considered to be significantly different (Steel et al., 1997).

\section{RESULTS AND DISCUSSIONS}

The weed management strategies had a significant effect on the biomass of sedges during both seasons (Figure 1). In both seasons, hand weeding was the most effective method for controlling sedges. During the year 2008, different weed control treatments were used, including spike hoeing, herbicide treatment, tine cultivation, hoeing and hand pulling reduced sedge biomass by 26.3 , $38.0,71.3,80.3$ and $95.4 \%$, respectively, as compared to weedy treatment or non-treated control. Accumulated dry weight of sedges was $159.46 \mathrm{~g} \mathrm{~m}^{-2}$ without any control measures. During the year 2009, the relative efficacy of the control measures was identical: compared with the weedy treatment; different weed control treatments reduced sedge biomass by $26.3,35.2,72.1,83.6$ and $95.0 \%$ with spike hoeing, herbicide treatment, tine cultivation, hoeing and hand pulling, respectively.

Similarly, the dry weights of broad-leafed weeds recorded in the 2008 season were reduced by $0.4,65.1,73.5,85.4$ and $96.5 \%$ with spike hoeing, herbicide treatment, tine cultivation, hoeing and hand pulling, respectively, compared with control. In the 2009 season, the quantities of broad-leaf weeds were also reduced by $2.2,62.4,68.2$, 76.7 and $93.0 \%$ with spike hoeing, herbicide treatment, tine cultivation, hoeing and hand pulling, respectively, compared with control (Figure 2).

The crop performance showed that the weed control measure significantly affected the number of fertile tillers (Table 2). During the 2008 season, the hand weeded plots had 375 fertile tillers per $\mathrm{m}^{2}$, whereas the tine cultivated plots had 350.44 per $\mathrm{m}^{2}$, the herbicide treated plots had 302.92 per $\mathrm{m}^{2}$ and the spike hoed plots had 255.00 per $\mathrm{m}^{2}$. The unweeded plots only formed 215.58 fertile 


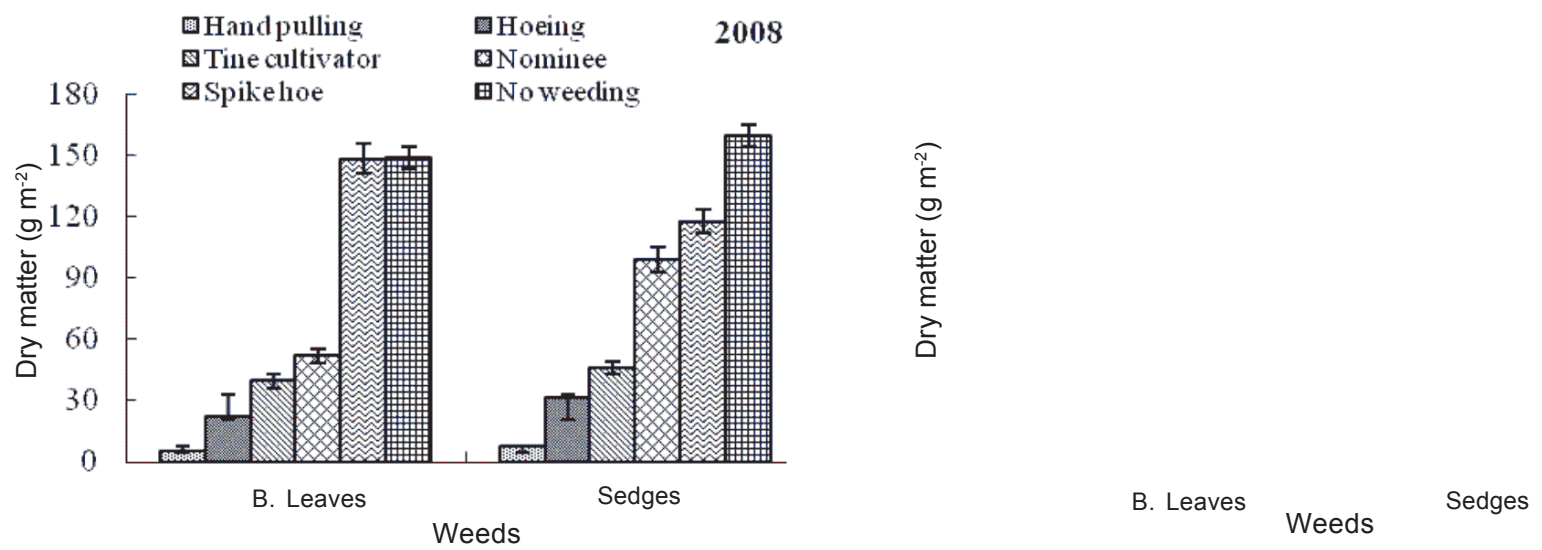

Figure 1 - The effect of the various weed management strategies on the accumulation of sedges and broad-leaved weeds at 45 days.
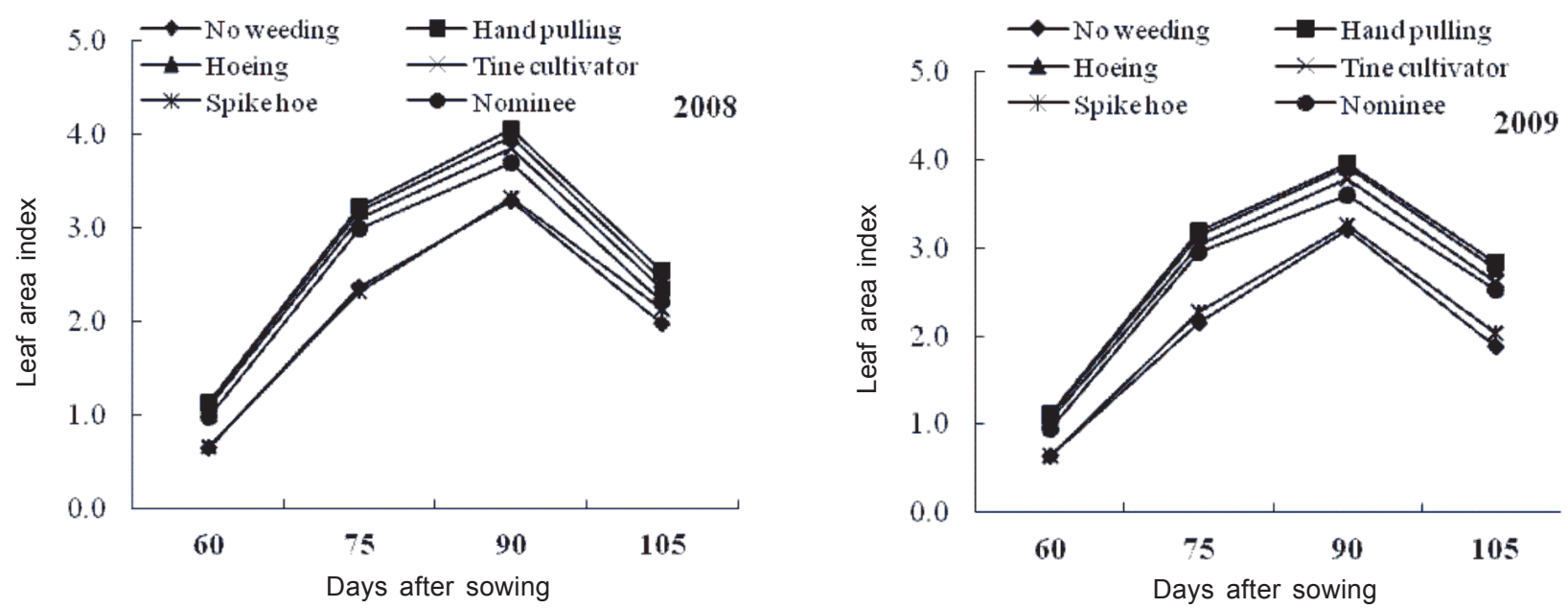

Figure 2 - The development of the leaf area index in response to the various weed control measures.

Table 2 - The effect of the various weed control measures on crop productivity

\begin{tabular}{|c|c|c|c|c|c|c|c|c|c|c|}
\hline \multirow[t]{2}{*}{ Treatment } & \multicolumn{2}{|c|}{$\begin{array}{l}\text { Productive tillers } \\
\qquad\left(\mathrm{m}^{-2}\right)\end{array}$} & \multicolumn{2}{|c|}{ Floret panilcle $^{-1}$} & \multicolumn{2}{|c|}{$\begin{array}{c}1000 \text { Grain weight } \\
\text { (g) }\end{array}$} & \multicolumn{2}{|c|}{$\begin{array}{l}\text { Grain yield } \\
\left(\text { tha }^{-1}\right)\end{array}$} & \multicolumn{2}{|c|}{ Benefit Cost Ratio } \\
\hline & 2008 & 2009 & 2008 & 2009 & 2008 & 2009 & 2008 & 2009 & 2008 & 2009 \\
\hline No weeding & $215.58 \mathrm{e}$ & $181.80 \mathrm{e}$ & $60.43 \mathrm{e}$ & $59.89 \mathrm{e}$ & $14.50 \mathrm{~d}$ & $15.17 \mathrm{e}$ & $1.47 \mathrm{e}$ & $1.27 \mathrm{e}$ & 0.64 & 0.61 \\
\hline Hand weeding & $375.11 \mathrm{a}$ & $363.60 \mathrm{a}$ & $78.15 \mathrm{a}$ & $76.25 \mathrm{a}$ & $20.87 \mathrm{a}$ & $20.40 \mathrm{a}$ & $4.45 \mathrm{a}$ & $4.35 \mathrm{a}$ & 1.58 & 1.72 \\
\hline Hoeing & $364.63 \mathrm{a}$ & $349.27 \mathrm{~b}$ & $75.92 \mathrm{a}$ & $75.49 \mathrm{a}$ & $20.60 \mathrm{a}$ & $20.17 \mathrm{a}$ & $4.21 \mathrm{a}$ & $4.11 \mathrm{a}$ & 1.58 & 1.72 \\
\hline Tine cultivator & $350.44 \mathrm{~b}$ & $343.12 \mathrm{~b}$ & $74.31 \mathrm{~b}$ & $73.16 \mathrm{~b}$ & $19.47 \mathrm{~b}$ & $19.20 \mathrm{~b}$ & $3.91 \mathrm{~b}$ & $3.81 \mathrm{~b}$ & 1.62 & 1.75 \\
\hline Nominee & $302.92 \mathrm{c}$ & $283.38 \mathrm{c}$ & $69.43 \mathrm{c}$ & $65.97 \mathrm{c}$ & $18.07 \mathrm{c}$ & $17.60 \mathrm{c}$ & $3.02 \mathrm{c}$ & $2.59 \mathrm{c}$ & 1.26 & 1.20 \\
\hline Spike hoe & $255.00 \mathrm{~d}$ & $243.19 \mathrm{~d}$ & $65.50 \mathrm{~d}$ & $62.89 \mathrm{~d}$ & $17.17 \mathrm{~d}$ & $16.52 \mathrm{~d}$ & $2.44 \mathrm{~d}$ & $2.05 \mathrm{~d}$ & 1.02 & 0.96 \\
\hline LSD & 13.80 & 5.69 & 1.53 & 1.02 & 0.54 & 0.26 & 0.29 & 0.26 & & \\
\hline
\end{tabular}


tillers per $\mathrm{m}^{2}$. Similarly, during the 2009 season, the most productive plots were the hand weeded ones (363.60 fertile tillers per $\mathrm{m}^{2}$ ), followed by the tine cultivated ones (343.12 per $\mathrm{m}^{2}$ ), the herbicide treated ones (283.38 per $\left.\mathrm{m}^{2}\right)$, the spike hoed ones $\left(243.19\right.$ per $\left.\mathrm{m}^{2}\right)$ and the untreated control plots (181.89 per $\mathrm{m}^{2}$ ).

Performance of weed control treatment on grain yield is presented in Table 2 , which shows that the choice of weed control measure had a marked effect on this critical trait. In the 2008 season, grain yield was statistically higher in the hand weeded plots $\left(4.45 \mathrm{t} \mathrm{ha}^{-1}\right)$, followed by the hoed ones $\left(4.21 \mathrm{t} \mathrm{ha}^{-1}\right)$, the tine cultivated ones $\left(3.91 \mathrm{t} \mathrm{ha}^{-1}\right)$, the herbicide treated ones $\left(3.02 \mathrm{t} \mathrm{ha}^{-1}\right)$ and the spike hoed ones $\left(2.44 \mathrm{t} \mathrm{ha}^{-1}\right)$. The yield was very poor when no weeding measures were taken (1.47 t ha-1). The 2009 season's outcomes were similar: hand weeding (4.35 $\left.\mathrm{t} \mathrm{ha}^{-1}\right)$, tine cultivation $\left(3.81 \mathrm{t} \mathrm{ha}^{-1}\right)$, herbicide treatment (2.59 $\left.\mathrm{t} \mathrm{ha}^{-1}\right)$ and control (1.27 $\left.\mathrm{t} \mathrm{ha}^{-1}\right)$.

The behavior of the leaf area index (LAI) of the crops is shown in Figure 2. During the 2008 season, the LAI measured at 90 DAS was highest in the hand weeded plots (4.07), followed by the canopy in the hoed plots (3.96), in the tine cultivated ones (3.85), in the herbicide treated ones (3.68), in the spike hoed ones (3.31) and in the no cultivation control (3.28). In the 2009 season, similarly, the hand weeded plots developed the highest LAI (3.96), followed by the hoed plots (3.91), the tine

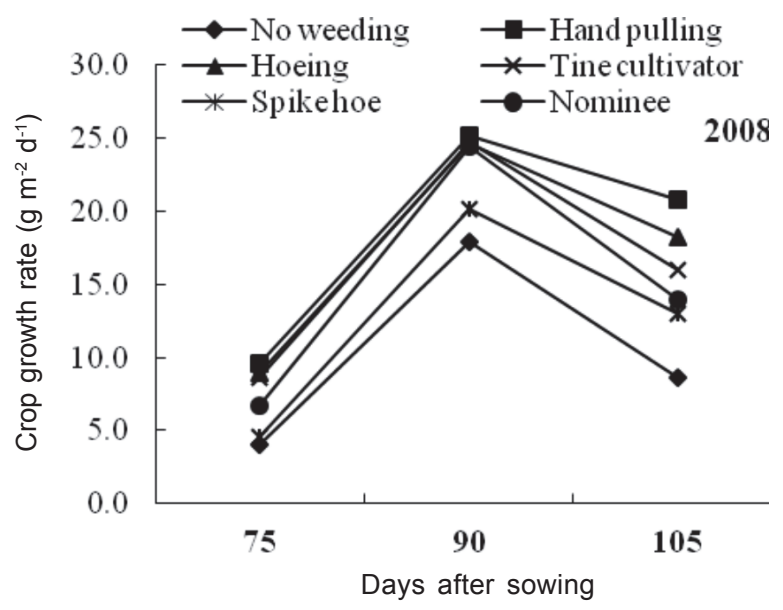

cultivated plots (3.79), the herbicide treated plots (3.59), the spike hoed plots (3.26) and the control (3.21). Crop growth rate (CGR) also responded to the weed control measure applied (Figure 3). It was highest for the hand weeded plots (25.14 $\mathrm{g} \mathrm{m}^{-2}$ per day), followed by the hoed ones (24.68 $\mathrm{g} \mathrm{m}^{2}$ per day), the tine cultivated ones (24.71 $\mathrm{g} \mathrm{m}^{-2}$ per day), the herbicide treated ones (24.38 $\mathrm{g} \mathrm{m}^{-2}$ per day), the spike hoed ones (20.14 $\mathrm{g} \mathrm{m}^{-2}$ per day) and the nonweeded ones (17.95 $\mathrm{g} \mathrm{m}^{2}$ per day). Similarly, in the 2009 season, CGR varied from 25.30 $\mathrm{g} \mathrm{m}^{-2}$ per day (hand weeded plots) to $17.99 \mathrm{~g} \mathrm{~m}^{-2}$ per day (non-weeded plots). The highest Benefit cost ratio (BCR) values were noted for the tine cultivated plots (1.62 in 2008, 1.75 in 2009), followed by the hand weeded plots (1.58 and 1.62), the herbicide treated plots (1.26 and 1.20), the spike hoed plots (1.02 and 0.96) and the control plots (0.64 and 0.61).

Grain quality was also affected by the choice of weed control measure (Table 3). In the 2008 harvest, grain protein concentration was highest in the hand weeded plots $(7.99 \%)$ followed by the tine cultivated ones $(7.56 \%)$, the herbicide treated ones $(7.31 \%)$, the spike hoed ones $(7.05 \%)$ and the non-weeded control ones $(6.61 \%)$. Similarly, protein concentration in the 2009 harvest varied from $7.96 \%$ (hand weeded plots) to $6.54 \%$ (non-weeded plots). The amylose concentration of grain from the hand weeded plots was $22.31 \%$ in 2008 and $22.23 \%$ in 2009; from the hoed plots the proportions

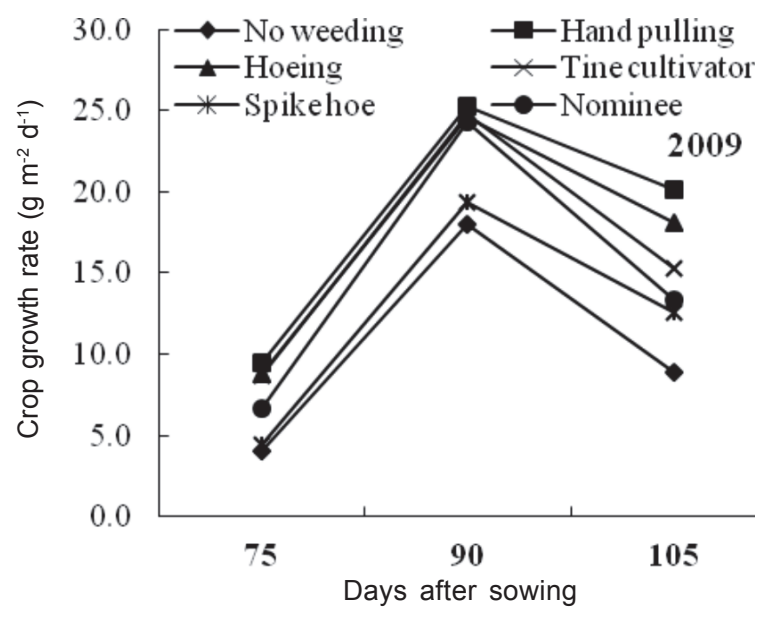

Figure 3 - The development of crop growth rate in response to the various weed control measures. 
Table 3 - The effect of the various weed control measures on grain quality

\begin{tabular}{|l|c|c|c|c|c|c|}
\hline \multirow{2}{*}{ Treatment } & \multicolumn{2}{|c|}{$\begin{array}{c}\text { Kernel protein concentration } \\
(\%)\end{array}$} & \multicolumn{2}{c|}{$\begin{array}{c}\text { Kernel amylose concentration } \\
(\%)\end{array}$} & \multicolumn{2}{c|}{$\begin{array}{c}\text { Kernel water absorption ratio } \\
(\%)\end{array}$} \\
\cline { 2 - 7 } & 2008 & 2009 & 2008 & 2009 & 2008 & 2009 \\
\hline No weeding & $6.61 \mathrm{e}$ & $6.54 \mathrm{e}$ & $18.63 \mathrm{f}$ & $18.56 \mathrm{f}$ & $2.94 \mathrm{f}$ & $2.86 \mathrm{f}$ \\
\hline Hand weeding & $7.99 \mathrm{a}$ & $7.96 \mathrm{a}$ & $22.31 \mathrm{a}$ & $22.23 \mathrm{a}$ & $4.47 \mathrm{a}$ & $4.39 \mathrm{a}$ \\
\hline Hoeing & $7.96 \mathrm{a}$ & $7.93 \mathrm{a}$ & $22.18 \mathrm{~b}$ & $22.08 \mathrm{~b}$ & $4.33 \mathrm{~b}$ & $4.24 \mathrm{~b}$ \\
\hline Tine cultivator & $7.56 \mathrm{~b}$ & $7.48 \mathrm{~b}$ & $21.30 \mathrm{c}$ & $21.22 \mathrm{c}$ & $4.08 \mathrm{c}$ & $3.94 \mathrm{c}$ \\
\hline Nominee & $7.31 \mathrm{c}$ & $7.22 \mathrm{c}$ & $19.27 \mathrm{~d}$ & $19.16 \mathrm{~d}$ & $3.68 \mathrm{~d}$ & $3.57 \mathrm{~d}$ \\
\hline Spike hoe & $7.05 \mathrm{~d}$ & $6.94 \mathrm{~d}$ & $18.95 \mathrm{e}$ & $18.84 \mathrm{e}$ & $3.33 \mathrm{e}$ & $3.22 \mathrm{e}$ \\
\hline LSD & 0.15 & 0.09 & 0.07 & 0.10 & 0.08 & 0.08 \\
\hline
\end{tabular}

were $22.18 \%$ and $22.08 \%$; from the tine cultivated plots $21.30 \%$ and $21.22 \%$; from the herbicide treated plots $19.27 \%$ and $19.16 \%$; from the spike hoed plots $18.95 \%$ and $18.84 \%$, and from the non-weeded control plots $18.63 \%$ and $18.56 \%$. The grains water absorption ratios in the 2008 and 2009 harvests were 4.47 and 4.39 (hand weeded plots), 4.33 and 4.24 (hoed plots), 4.08 and 3.94 (tine cultivated plots), 3.68 and 3.57 (herbicide treated plots), 3.33 and 3.22 (spike hoed plots) and 2.94 and 2.86 (non-weeded control plots).

Weeds are a major constraint for DSR productivity, having a greater impact on yield than other pests (Savary et al., 1997; Chauhan et al., 2011). The various weed control measures had a positive effect on weed biomass accumulation, with four times of hand weeding proving to be the most effective method. Hoeing was effective when compared with that of spike hoeing, herbicide treatment and tine cultivation. A similar ranking of weed control measures has been noted by Akbar et al. (2011). Tine cultivation reduced weed biomass accumulation more than spike hoeing or herbicide treatment did, perhaps because it damaged weeds growing within the rows, thereby delaying their flowering. A second possibility might be that the beushening treatment destroyed all singlestemmed weeds present in the plots (Bhagirath 2012; Rao et al., 2007). The herbicide treatment (Nominee) showed generally less effectiveness than that of hand weeding, hoeing and tine cultivator, but better than that of control and spike hoe. This difference in effectiveness may be a result of the active ingredient of the herbicide and its mode of action, as it inhibits acetolactate synthase (ALS).

LAI is a useful indicator of crop photosynthetic activity, and has responded positively to a reduction in weed pressure. CGR has been used to predict the grain yield of various cereal crops, since reproductive success is highly dependent on plant size (Shipley, 2006; Grotkopp et al., 2007). Like LAI, CGR has also responded positively to a reduction in weed pressure, presumably because the reduced competition for resources meant that the crop plants were better able to out-compete the weeds (Matloob et al., 2015b). Hand weeding succeeded in increasing the number of fertile tillers formed per unit area by $47 \%$, and this trait generally responded positively to a reduction in weed pressure. Reason might be aerobic soil conditions: emerging DSR seedlings were less competitive with concurrently emerging weeds (Ekleme et al., 2009).

The weeding regimes induced significant variation in grain yield in particular, hand weeding and hoeing improved yield over the non-weeded control by $70 \%$ and $67 \%$, respectively. Any reduction in weed pressure can be expected to promote yield as it lessens the strength of the competition for resources between the crop and the weeds (Phoung et al., 2005). The benefit of tine cultivation was a $64 \%$ increase in grain yield, reflecting a good level of control over weeds growing among the rows (Fazlollah et al., 2011). The herbicide performed less well, achieving only a $50 \%$ benefit over the non-weeded control. Suppressing weeds also promoted grain quality, an important determinant of market price (Singh, 2008; 
Farooq et al., 2011). The improvement in grain amylose and protein concentration achieved by weed control likely reflected a reduced level of weed pressure (Rao et al., 2007; Singh, 2008; Farooq et al., 2011).

The weed biomass in response to the experimental treatments used during the course of the study has been arranged in Table 4. A close observation of the table shows that the mean of weed biomass for both years showed a statistically different biomass for all the experimental treatments. Maximum weed biomass was produced in case of the control treatment (where no weeding was done). Hand pulling of weeds resulted in minimum weed biomass showing a reduction of around 95\% when compared with that of control. It was followed by that of hoeing $(81.41 \%$ reduction) and tine cultivator $(71.30 \%$ reduction in weed biomass). Minimum reduction in weed biomass was observed in case of weed control by means of spike hoe (14.31\% reduction) followed by that of chemical weed control by Nominee 100 SC (49.76\% reduction).

In summary, weeds are a major constraint in achieving good crop yields of DSR. The present study revealed that hand weeding, hoeing, tine cultivation and herbicide treatment (bispyribac sodium) provided a level of control of, respectively, 95\%, 81\%, 71\% and $50 \%$, compared to a non-weeded control. Although hand weeding was the most effective means of control, tine cultivation was more economical, delivering a BCR of 1.75 vs 1.72. Weeds can be effectively and economically controlled in DSR using tine cultivation.

\section{ACKNOWLEDGEMENT}

Research facilities provided by the University of Agriculture Faisalabad to conduct this research are gratefully acknowledged. The authors are also thankful to Robert Koebner (smartenglish2008@gmail.com) for reviewing the article.

\section{LITERATURE CITED}

AULAKH, J. S. et al. Integrated Palmer amaranth management in glufosinate-resistant cotton: II. Primary, secondary and conservation tillage. Agronomy, v. 3, n. 1, p. 28-42, 2013.
AKBAR, N. et al. Weed management improves yield and quality of direct seeded rice. Austr. J. Crop Sci., v. 5, n. 6, p. 688-694, 2011.

BECKIE, H. J. Herbicide-resistant weed management: focus on glyphosate. Pest. Manage. Sci., v. 67, n. 9, p. 1037-1048, 2011.

BHAGIRATH, S. C. Weed ecology and weed management strategies for dry-seeded rice in Asia. Weed Technol., v. 26, n. 1, p. 1-13, 2012.

CHAHAL, P. S.; JHALA, A. J. Herbicide programs for control of glyphosate-resistant volunteer corn in glufosinateresistant soybean. Weed Technol., v. 29, n. 3, p. 431-443, 2015.

CHAHAL, P. S. et al. Efficacy of pre-emergence and postemergence soybean herbicides for control of glufosinate-, glyphosate, and imidazolinone-resistant volunteer corn. J. Agric. Sci., v. 6, n. 8, p. 131-140, 2014.

CHAUHAN, B. S.; JOHNSON, D. E. Row spacing and weed control timing affect yield of aerobic rice. Field Crops Res., v. 121, n. 2, p. 226-231, 2011.

EKLEME, F. Response of upland rice cultivars to weed competition in the savannas of West Africa. Crop Protec., v. 28 , n. 1, p. 90-96, 2009.

FAROOQ, M. Rice direct seeding: Experiences, challenges and opportunities. Soil Till. Res., v. 111, n. 2, p. 87-98, 2011.

FAZLOLLAH, E. C. H. Evaluation of traditional, mechanical and chemical weed control methods in rice fields. Austr. J. Crop Sci., v. 5, n. 8, p. 1007-1013, 2011.

FISCHER, A. J.; HILL, J. E. Weed control programs. Rice Production Workshop. Oakland, CA: University of California, Division of Agriculture and Natural Resources, 2004. p. 1-9.

GROTKOPP, E.; REJMANEK, M. High seedling relative growth rate and specific leaf area are traits of invasive species: Phylogenetically independent contrasts of woody angiosperms. Am. J. Bot., v. 94, n. 4, p. 526-532, 2007.

HUNT, R. Plant growth analysis. London: Edward Arnold, 1978. 67 p.

JOHNSON, D. E.; MORTIMER. A. M. Issues for integrated weed management and decision support in direct-seeded rice. In: WORLD RICE RESEARCH CONFERENCE (Rice is Life: Scientific Perspective for the $21^{\text {st }}$ century). Tokyo and Tsukuba, Japan: IRRI and Japan International Research Center for Agricultural Sciences, 2005. p. 211-214. 
KHALIQ, A.; MATLOOB, A. Weed management in dry seeded fine rice sown under varying row spacing in a ricewheat system of Pakistan. Plant Prod. Sci., v. 17, n. 3, p. 321-332, 2014.

KHALIQ, A. et al. Bio-economic and qualitative impact of reduced herbicide usage in direct seeded fine rice through multipurpose tree water extracts. Chile. J. Agric. Res., v. 72, n. 3, p. $350-357,2012$.

LADHA, J. K. et al. Sustainability of the rice-wheat cropping system. J. Crop Improv., v. 19, n. 1-2, p. 125-136, 2007.

MATLOOB, A. et al. Weeds of rice in Asia: Problems and opportunities. Adv. Agron., v. 130, p. 291-336, 2015 a.

MATLOOB, A. et al. Dry matter accumulation and growth response of zero tilled direct seeded fine rice to different weed competition durations and sowing times. Int. J. Agric. Biol., v. 17, n. 1, p. 41-50, 2015 b.

PHOUNG, L. T. et al. Suppressing weeds in direct seeded lowland rice: effects of methods and rates of seeding. J. Agron. Crop Sci., v. 191, n. 3, p. 185-194, 2005.

RAO, A. N. et al. Weed management in direct seeded rice. Adv. Agron., v. 93, n. 1, p. 153-255, 2007.
SAQIB, M. et al. Development and appraisal of economical and sustainable approach for weed management in drill seeded aerobic rice (Oryza sativa L.). Pak. J. Agric. Sci., v. 49, n. 3, p. 281-287, 2012.

SAVARY, S. et al. A characterization of rice pests and quantification of yield losses in the rice-wheat system of India. Crop Protec., v. 16, n. 4, p. 387-398, 1997.

SHIPLEY, B. Net assimilation rate, specific leaf area and leaf mass ratio: which is most closely correlated with relative growth rate? A meta-analysis. Funct. Ecol., v. 20 n. 4, p. $565-574,2006$.

SING, G. Integrated weed management in direct seeded rice. In: SING, Y. Direct seeding of rice and weed management in the irrigated rice-wheat cropping system of the IndoGangetic plains. Los Baños, Philippines: IRRI, 2008. p. 19-36.

SING, Y. et al. The implications of land preparation, crop establishment method and weed management on rice yield variation in the rice-wheat system in the Indo-Gangetic plains. Field Crops Res., v. 121, n. 1, p. 64-74, 2011.

STEEL, R. G. D. Principles and procedure of statistics. In: A biometrical approach. 3.ed. New York: McGraw Hill Book, 1997. p. 352-358. 